\title{
GENETIC AND PHENOTYPIC TREND OF MILK PRODUCTION TRAITS AND AGE AT FIRST CALVING APPLYING RANDOM REGRESSION MODEL IN FRIESIAN CATTLE IN EGYPT
}

\author{
M.H. Mohamed ${ }^{1}$,M.H. Khalii ${ }^{2}$, M.M. Iraqi ${ }^{2}$ and S.M. Zahed ${ }^{1}$ \\ 1-Animal Production Research Institute, Agricultural Research Center, Ministry of Agriculture and Land \\ Reclamation, Dokki, Giza, Egypt, 2 - Department of Animal Production, Faculty of Agriculture at Moshtohor, \\ Benha University, Egypt, Corresponding author: maher.khalil@fagr.bu.edu.eg
}

\author{
Received: 28/11/2019 Accepted: 26/3/2020
}

\section{SUMMARY}

The aim of this study was to detect genetic and phenotypic trends for test-day (TD) milk, fat and protein yields and age at first calving (AFC) in Frisian cattle in Egypt applying the random regression model (RRM). Data of 5237 TD milk yield traits were recorded for 953 Friesian cows, daughters of 208 sires and 944 dams from two herds in the Animal Production Institute (APRI), Egypt. Ten-month classes of lactation days were considered for the TD yields. The model included the random effects of direct additive genetic, permanent environment and error, while the fixed effects were herd-year-season of calving and parity, which was modeled by Orthogonal Legendre Polynomials. The additive genetic variance at first TD for milk, fat, protein yields and AFCwere $4.7 \mathrm{~kg}, 13.3 \mathrm{~g}, 5.3 \mathrm{~g}$ and 2.8 monthrespectivelyand increased until the fourth, decreased until the lowest value at the tenth TD for milk but fat and protein yields the lowest value at the ninth TD.The lowest value of AFC was at the sixth TD then increased until the tenth TD. Heritability estimates at first TD were 0.12, 0.25, 0.25 and 0.05 for TDMY, TDFY, TDPY and AFC, respectively, and increased until the third for TDFY, TDPY and AFC but TDMY trait reached the highest value at the fourth TD, then decreased at the tenth TD.But reached the lowest value at sixth TD, and increased until the tenth TD. The phenotypic trendfor TDMY decreased by 26 to $18 \mathrm{~kg}$ from the first to the fifth TD, then it increased until the tenth TD. The phenotypic trend was started by $44 \mathrm{~g}$ and $18 \mathrm{~g}$ for fat and protein, respectively until the fourth TD then decreased until the ninth TD. The genetic trends were slightly positive for all traits, indicating that the selection program performs correctly.

Keywords:Test day milk yield, random regression model, genetic and phenotypic trends

\section{INTRODUCTION}

Random regression models (RRM) are currently used in the prediction of breeding values and in the estimation of the variance components for milk production traits of dairy cattle in several countries. Direct modeling of test day (TD) records instead of 305-d yields allows the shape of the lactation curve to be modeled with subsequently more precise adjustment for temporary environmental effects, avoidance of extended records for culled cows or lactations in progress, and evaluation of lactation persistency (Jamrozik and Schaeffer, 1997). In the basic structure of a RRM, the fixed part includes effects peculiar to all cows on the same test day and effects specific to cows on a given test day, such as pregnant or diseased, plus a factor accounting for the yield level on a specific day in milk (Ptak and Schaeffer, 1993) whereas individual lactation curves are fitted by random regression coefficients (Schaeffer and Dekkers, 1994; Jamrozik and Schaeffer, 1997). This feature of RRM allows for the prediction of breeding values and estimatingthe (co)variance functions throughout the whole lactation. Mean lactation curves are usually estimated on a large number of records and are characterized by quite regular patterns. As stated by Schaeffer 2004the use of either mathematical functions or fixed intervals of days in milk will generally lead to the same results. In this study, the trend is investigated at the phenotypic level by a fixed regression analysis of individual deviations around the mean curves for milk yield of first lactation Canadian Holsteins using some of the functions proposed to fit random effects in RRM for milk production traits in cattle. The aim of the present study was to estimate variance components, heritability and genetic and phenotypic trend for Friesian cattle raised in Egypt.

\section{MATERIAL AND METHODS}

\section{Management and data structure:}

A total of 5237 test-day milk, fat and protein yield records from 2000 to 2016 years were used in this study as shown in Table1.Cows were fed, on a ration consisting cotton seed cakes, barley wheat and rice bran, cows fed mainly on berseem and rice straw. In addition concentrates feed mixture from December to April. Mineral mixture bricks were offered adlibitum as soled minerals mixture in front animals, and on a balanced ration of a concentrates according to their production and weight. Limited amount of 
clover hay was used when available. Animals housed under open sheds covered with 3.5-4 meters high roofs. Heifers were bred for the first time when they reached $18-22$ months or $350 \mathrm{~kg}$ body weight. Cows were artificially inseminated not before 60 days of calving using frozen semen from U.S.A and Canada. Cows milked two times a day by milking machine.

Data collected at monthly intervals in three experimental herds (Sakha and El karada in Kafrelshikh Governorate and El Serw in Damietta governorate) belonging to Animal Production Research Institute (APRI), Ministry of Agriculture, Egypt. Test-day milk yield (TDMY) records were measured based on an alternative am-pm monthly recording scheme. Milking was practiced twice a day at $7 \mathrm{am}$ and $4 \mathrm{pm}$ throughout the lactation period. In general, using TD models could have advantages over a 305-day model (Wilmink, 1987; Danell, 1982; Keown and VanVLeck, 1971). Cows with less than four TD records per lactation were excluded from the data set, while the maximum number of test day records per lactation was 10 records. Moreover, up normal phenotypic values of daily milk yield, fat and protein yield were removed from the dataset. The structure of the data analyzed is shown in Table1.

Table1. Structure of test day data analyzed for cattle's

\begin{tabular}{ll}
\hline Item & Data \\
\hline No. of sires & 208 \\
No. of dams & 944 \\
No. of base animals & 953 \\
No of non-base animals & 1560 \\
Total number of animals & 2513 \\
Total number of lactation records & 5237 \\
\hline
\end{tabular}

\section{Measuring fat and protein percentages in milk:}

Fat and protein percentages were measured by the automated method of infrared absorption spectrophotometry (Milk-o-Scan; Foss Electric, Hillerpd, Denmark) at the Dairy Services Unit, Animal Production Research Institute, Sakha, Kafr El-Sheikh Governorate. The device needs a set of solutions:The first solution is used to wash the device after the analysis of the samples and before turning it off the name of this solution none foaming Stella $0.5 \%$ (Foss electric company, Denmark). The second solution is used to reset the device which gives the readings 0.000 so it is ready to read the new samples and its name is Triton $\mathrm{x}-100$ and we use only 1 $\mathrm{cm} /$ liter of distilled water, and finally we have to give the device the order Prog. 2 then Prog. 3 then Prog. 4, and then the device is programmed to read the cow milk samples.After that the percentages of fat and protein had been converted to yields in grams.

\section{Statistical analyses: \\ Estimating variance (co) components using random regression model:}

The monthly test-day milk yield (TDMY) were measured between 4 and 304 days in milk (DIM), divided into 10 classes. The first class included milk yield between 4 and 30 DIM, the second included milk yield between 31 and 60 DIM, and so on until the last class, which included milk yield between 270 and 304 DIM. The orthogonal polynomials of standardized units of time have been recommended as covariables(Kirkpatrick et al., 1990; Meyer, 1998). Orthogonal polynomials have computational advantages; the primary general advantage is the reduced correlations among the estimated coefficients.

The standardized unit of time, $w$, ranges from -1 to +1 , was derived as:

$t^{*}=\frac{2\left(t-t_{\min }\right)}{t_{\max }-t_{\min \bar{\Xi}}}-\mathbf{1}$

Wheret $_{\min }$ is the earliest date (or the youngest age) and $t_{\max }$ is the latest date (or oldest age) represented in the data. The first six Legendre polynomial functions of standardized units of time are given in Table 2. Thus, if $\mathrm{w}=-0.2$, then the coverable that would go into the model (for order equal to 5) are shown in the last column of Table 2. Coverable based upon orthogonal polynomials are small numbers that reduce problems with rounding errors, and they provide relatively small correlations between the estimated regression coefficients.

Table2. The first six Legendre polynomial functions of standardized units of time

\begin{tabular}{lll}
\hline Order & & For $\mathbf{w}=-\mathbf{0 . 2}$ \\
\hline 0 & $0.7071 w^{0}$ & 0.7071 \\
1 & $1.2247 w^{1}$ & -0.2449 \\
2 & $-0.7906 w^{0}+2.3717 w^{2}$ & -0.6957 \\
3 & $-2.8062 w^{1}+4.6771 w^{3}$ & 0.5238 \\
4 & $0.7955 w^{0}-7.9550 w^{2}+9.2808 w^{4}$ & 0.4921 \\
5 & $4.3973 w^{1}-20.5206 w^{3}+18.4685 w^{5}$ & -0.7212 \\
\hline
\end{tabular}


And so on, the first six Legendre polynomial functions can be put into a matrix of polynomial coefficients $(\Lambda)$ as:

$\Lambda^{\prime}=\left(\begin{array}{rrrrrr}0.7071 & 0 & 0 & 0 & 0 & 0 \\ 0 & 1.2247 & 0 & 0 & 0 & 0 \\ -0.7906 & 0 & 2.3717 & 0 & 0 & 0 \\ 0 & -2.8062 & 0 & 4.6771 & 0 & 0 \\ 0.7955 & 0 & -7.9550 & 0 & 9.2808 & 0 \\ 0 & 4.3973 & 0 & -20.5206 & 0 & 18.44685\end{array}\right)$

Now we can define another matrix, M, as a matrix containing the polynomials of standardized time values. Legendre polynomials are defined within the range of values from -1 to +1 . Thus, ages or time periods have to be standardized (converted) to the interval between -1 to +1 . The formula is

$$
\mathrm{M}=t^{*}=\frac{2\left(t-t_{\min }\right)}{t_{\max }-t_{\min }}-\mathbf{1} \text { this gives } \Phi=\mathrm{M} \Lambda .
$$

Orthogonal polynomials tend to reduce the correlations between estimated regression coefficients. This is advantageous, because the estimates would converge faster to the maximum or appropriate posterior distribution. There are other kinds of orthogonal polynomials, but Legendre polynomials are probably the easiest to calculate and utilize. Covariables based upon orthogonal polynomials are small numbers that reduce problems with rounding errors, and they provide relatively small correlations between the estimated regression coefficients.

Variance-covariance components were estimated by REML using the computer package VCE6 (Groeneveld et al., 2010). The animal model was:

$$
Y_{i j k l}=H Y S_{i}+\sum_{m=1}^{4} \beta_{k m} Z_{j l m}+\sum_{m=1}^{4} \alpha_{j m} Z_{j l m}+P e_{j}+e_{i j k l}
$$

where: $\mathrm{Y}_{\mathrm{ijk} l}$ is the record lon trait within lactation made on herd-year-season (HYS) subclass $i$ for the $j^{\text {th }}$ cow belonging to $\mathrm{k}^{\text {th }}$ subclass ( $\mathrm{k}$ ranged from 1 to 10 starting with $\mathrm{k}=1$ and increased by 1 every 30 days thereafter along the trajectory from 4 to $304-\mathrm{d}$ ); $\mathrm{HYS}_{\mathrm{i}}$ is the fixed effect of herd-year-season, $\mathrm{Pe}_{\mathrm{j}}=$ random effect of permanent environment associated with all TD yields of the $\mathrm{j}^{\text {th }}$ cow; $\beta_{\mathrm{km}}$ and $\alpha_{\mathrm{jm}}=$ fixed and random regression coefficient, and $\mathrm{e}_{\mathrm{ijkl}}=$ random residual effect as sociated with $\mathrm{Y}_{\mathrm{ijk} l}$.

The VCE6 program applying the Random Regression Model (RRM) was used to analyze the data using the Legendre polynomials method (Kirkpatrick et al., 1990). The general RRM can be represented in matrix notation as:

$$
\mathrm{Y}=\mathrm{Xb}+\mathrm{Za}+\mathrm{Wp}+\mathrm{e}
$$

Where, $\mathrm{Y}=$ vector of observations on animal; $\mathrm{b}=$ vector of the fixed effects (HYS is the fixed effect of herd-year-season combination and $\mathrm{P}$ is the fixed effect of the $1^{\text {th }}$ parity $(1=12$ levels for all parities $)$; a $=$ vector of solutions for additive genetic random coefficients; $p=$ vector of solutions for permanent environmental random coefficients; $\mathrm{e}=$ vector of $\mathrm{N}$ different residuals; $\mathrm{X}, \mathrm{Z}$, and $\mathrm{W}=$ incidence matrices for fixed and random genetic and permanent environmental random effects, respectively. The assumptions with respect to the components of the model were (Jamrozik and Schaeffer, 1997; Schaeffer, 2004):

$$
\left(\begin{array}{l}
a \\
p \\
e
\end{array}\right) \square N(0, V) \text { where, } V=\operatorname{Var}\left(\begin{array}{l}
a \\
p \\
e
\end{array}\right)=\left(\begin{array}{ccc}
G \otimes A & 0 & 0 \\
0 & I \sigma_{p}^{2} & 0 \\
0 & 0 & R
\end{array}\right)
$$

where $\mathrm{G}$ and $\mathrm{P}$ are (co)variance matrix of additive genetic and permanent environment random regression coefficients, respectively; $\mathrm{A}$ is an additive genetic relationship matrix among the cows; $\bigotimes$ is a Kronecker product function; I is identity matrix and $\mathrm{R}$ is the diagonal matrix of temporary environmental variances. The mixed model equations for this model would be:

$$
\begin{gathered}
V=\left(\begin{array}{ccc}
X^{\prime} X & X^{\prime} Z & X^{\prime} W \\
Z^{\prime} X & Z^{\prime} Z+G^{-1} \otimes A^{-1} & Z^{\prime} W \\
W^{\prime} X & W^{\prime} Z & W^{\prime} W+I \otimes P^{-1}
\end{array}\right)\left(\begin{array}{l}
b \\
a \\
p
\end{array}\right)=\left(\begin{array}{c}
X^{\prime} Y \\
Z^{\prime} Y \\
W^{\prime} Y
\end{array}\right) \\
E\left[\begin{array}{c}
y \\
a \\
p \\
e
\end{array}\right]=\left[\begin{array}{c}
X b \\
0 \\
0 \\
0
\end{array}\right] ; \begin{array}{r}
V(a)=K_{a} \otimes A ; \\
V(p)=K_{p} \otimes I ; \\
V(e)=R,
\end{array}
\end{gathered}
$$

Where $k_{a}$ and $k_{p}$ are the genetic and permanent environmental covariance matrices between random regression coefficients, respectively. A is the additive genetic relationship matrix; I is an identity matrix, and $\mathrm{R}$ represents a diagonal matrix containing the residual variances.

The genetic (G) and permanent environmental $(\mathrm{P})$ covariance between test-days were estimated using:

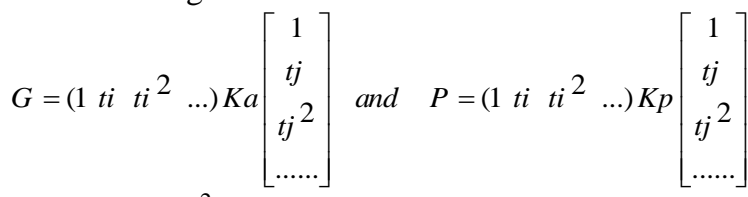

Heritabilities $\left(\mathrm{h}^{2}\right)$ are computed using the package of VCE6 as (Groeneveld et al., 2010):

$$
h^{2}=\frac{\sigma_{g i}^{2}}{\sigma_{g i}^{2}+\sigma_{p e_{i}}^{2}+\sigma_{e i}^{2}}
$$

Where: $\sigma_{\text {gi }}^{2}$ is the additive genetic variance of the $i^{\text {th }}$ $\mathrm{TD} ; \sigma_{\mathrm{pi}}^{2}$ is the permanent environmental variance and $\sigma_{\text {ei }}^{2}$ is the residual variance.

\section{Predicting the breeding values of the genetic trend:}

Predicted breeding values (PBVs) for cows were estimated using the computer package of PEST program (Groeneveld et al., 2001) for test day milk, fat and protein yields and age at first calving according to the following model:

$$
\mathrm{y}=\mathrm{Xb}+\mathrm{Za} \mathrm{a}+\mathrm{Zc} \mathrm{c}+\mathrm{e}
$$

where: $\mathrm{y}=$ Vector of observations, $\mathrm{X}=$ Incidence matrix relating fixed effects to $y, b=$ Vector of an overall mean and fixed effects, (HYS is the fixed effect of herd-year-season combination and $\mathrm{P}$ is the fixed effect of the $1^{\text {th }}$ parity $(1=12$ levels for all parities), $\mathrm{Za}=$ Incidence matrix relating direct additive genetic effects to $\mathrm{y}, \mathrm{a}=$ Vector of random effect (direct additive genetic associated with the 
incidence matrix $\mathrm{Za}$ ), $\mathrm{Zc}=$ Incidence matrix for permanent environmental effect, $\mathrm{c}=$ Vector of permanent environmental effect associated with the incidence matrix $\mathrm{Zc}$ and $\mathrm{e}=$ Vector of random residual effects $\mathrm{N}\left(0, \mathrm{I}^{2}{ }_{\mathrm{e}}\right)$; $\mathrm{I}$ is an identity matrix.

Solutions for the equations of animals were computed from the pedigree file, one animal at a time for animals with records and animals without records (sires and dams). A diagonal element $\left(\mathrm{d}_{\mathrm{t}}\right)$ and an adjusted right-hand side $\left({ }^{\mathrm{y}^{*}}\right)$ were accumulated with each pedigree file record for the $\mathrm{t}^{\text {th }}$ animal. For the animals with and without records, the formula used to estimate the PBV was that of (Kennedy 1989):

$$
\mathrm{PBV}=\left[{ }_{\mathrm{t}}^{\mathrm{y}} / \mathrm{d}_{\mathrm{t}}\right]
$$

The predicted error variances (PEV) of predicted breeding values (PBVp) were estimated for each individual as: $\mathrm{PEV}_{\mathrm{p}}=\mathrm{d}_{\mathrm{j}} \sigma^{2}{ }_{\mathrm{e}}($ Kors gaard et al., 2002); where $d_{j}$ is the $j^{\text {th }}$ diagonal element of inverse of the appropriate block coefficient matrix and $\sigma^{2}$ is the residual variance. The accuracy of PBV for each individual was estimated according to Henderson (1975) as:

$$
r \hat{A}=\sqrt{1+F_{j}-d_{j} \alpha_{a}}
$$

Where

$r_{\hat{A}}^{\hat{\Lambda}}=$ the accuracy of prediction of the $\mathrm{i}^{\text {th }}$ animal's breeding value; $F_{j}=$ inbreeding coefficient of animals (assumed equal to be zero); $d_{j}$ was defined before; and $\alpha_{\mathrm{a}}=\sigma_{\mathrm{e}}^{2} / \sigma_{\mathrm{a}}^{2}$.

\section{Plotting the genetic and phenotypic trends:}

The phenotypic trend was measured as the regression of least squares means on years. The breeding values of the animals with records and without records were estimated using the PEST program (Groeneveldet al., 2001). Accordingly, the genetic trend was measured by regressing the breeding values on years.

\section{RESULTSANDDISSCUTION}

\section{Means and variations:}

Number of observations, means and their standard deviations and coefficients of variation (CV) for thetraits studied are shown in Table 3.

Table3. Number of observations, means, and standard deviations (SD) and coefficients of variation

\begin{tabular}{|c|c|c|c|c|c|c|c|c|c|c|c|c|c|c|}
\hline \multirow{2}{*}{$\begin{array}{l}\text { TD } \\
\text { NO. }\end{array}$} & \multirow{2}{*}{$\begin{array}{l}\text { No. of } \\
\text { obs. for } \\
\text { all milk } \\
\text { traits }\end{array}$} & \multicolumn{3}{|c|}{ TDMY } & \multicolumn{3}{|c|}{ TDFY } & \multicolumn{3}{|c|}{ TDPY } & \multicolumn{4}{|c|}{ AFC } \\
\hline & & $\begin{array}{c}\text { Mean } \\
\text { kg }\end{array}$ & $\begin{array}{l}\mathrm{SD} \\
\mathrm{kg}\end{array}$ & $\begin{array}{l}\mathrm{Cv} \\
\%\end{array}$ & $\begin{array}{c}\text { Mean } \\
\text { Kg }\end{array}$ & $\begin{array}{l}\mathrm{SD} \\
\mathrm{kg}\end{array}$ & $\begin{array}{l}\mathrm{Cv} \\
\%\end{array}$ & $\begin{array}{c}\text { Mean } \\
\text { kg }\end{array}$ & $\begin{array}{l}\mathrm{SD} \\
\mathrm{Kg}\end{array}$ & $\begin{array}{l}\mathrm{Cv} \\
\%\end{array}$ & $\begin{array}{l}\text { N. of } \\
\text { obs. }\end{array}$ & $\begin{array}{l}\text { Mean } \\
\text { Mo. }\end{array}$ & $\begin{array}{l}\text { SD } \\
\text { Mo. }\end{array}$ & $\begin{array}{l}\mathrm{Cv} \\
\%\end{array}$ \\
\hline 1 & 809 & 10.4 & 5.6 & 46 & 0.43 & 0.2 & 55 & 0.32 & 0.2 & 51 & 533 & 32.2 & 5.8 & 15 \\
\hline 2 & 861 & 11.3 & 6.6 & 45 & 0.43 & 0.2 & 50 & 0.31 & 0.2 & 51 & 566 & 32.3 & 5.7 & 15 \\
\hline 3 & 870 & 12.9 & 5.2 & 44 & 0.45 & 0.3 & 56 & 0.31 & 0.2 & 50 & 573 & 32.2 & 5.8 & 15 \\
\hline 4 & 866 & 11.4 & 5.1 & 45 & 0.39 & 0.2 & 50 & 0.29 & 0.1 & 47 & 566 & 32.2 & 5.8 & 15 \\
\hline 5 & 621 & 11.1 & 5.8 & 43 & 0.40 & 0.2 & 51 & 0.28 & 0.1 & 46 & 384 & 32.2 & 4.3 & 13 \\
\hline 6 & 457 & 10.4 & 5.6 & 44 & 0.35 & 0.2 & 53 & 0.27 & 0.1 & 48 & 268 & 32.4 & 4.4 & 14 \\
\hline 7 & 331 & 10.2 & 5.6 & 45 & 0.36 & 0.2 & 55 & 0.26 & 0.1 & 48 & 194 & 32.2 & 5.5 & 14 \\
\hline 8 & 227 & 10.6 & 5.6 & 48 & 0.33 & 0.2 & 54 & 0.24 & 0.1 & 48 & 123 & 32.2 & 5.6 & 14 \\
\hline 9 & 135 & 9.2 & 5.6 & 50 & 0.33 & 0.2 & 53 & 0.23 & 0.1 & 48 & 73 & 32.2 & 5.8 & 15 \\
\hline 10 & 59 & 9.4 & 5.9 & 53 & 0.32 & 0.2 & 58 & 0.25 & 0.1 & 57 & 32 & 32.3 & 5.7 & 15 \\
\hline
\end{tabular}
(CV\%) for test day (TD) milk, fat and protein yields and age at first calving (AFC)

$\mathrm{TD}=$ Test-day, TDMY = Test-day milk yield, TDFY = Test-day fat yield, TDPY $=$ Test-day protein yield and AFC $=$ Age at first calving.

Means and standard deviations of test-day milk yield increased from the first test day (TDMY1) to the peak in the third test day (TDMY3) which was $12.9 \pm 5.2 \mathrm{~kg}$. TDM decreased from the fourth and fifth TDMY which were $11.1 \pm 5.8 \mathrm{~kg}$ and fixed from the sixth TDMY to the eighth test day which were $10.6 \pm 5.6 \mathrm{~kg}$ and in the lasttwotest daywere 9.4 \pm 5.9 $\mathrm{kg}$ (Table3). Means and standard deviations of test day fat yield were fixed from the first (TDFY1) to the seventh test day fat (TDFY7) which was $0.36 \pm 0.2 \mathrm{~g}$. TDFY decreased from the eighth TDFY8 to the last TDFY10 which were $0.32 \mathrm{~g} \pm 0.2 \mathrm{~g}$.(Table3).For protein-test day yield, the means were fixed from the first(TDPY1) to the fifth test day protein (TDPY5) which was $0.28 \pm 0.1 \mathrm{~g}$. TDPY decreased from the sixth TDPY6 to the last TDPY10 which were 0.25 $\pm 0.1 \mathrm{~g}$. For age at first calving (AFC) the mean was nearly constant to be $32 \pm 5$ month. Coefficients of variation ranged from $43 \%$ to $53 \%$ for TDMY, from
$50 \%$ to $58 \%$ for TDFY, from $46 \%$ to $57 \%$ for TDPY andfrom 0.13 to 0.15 for age at first calving.

\section{Variances:}

Estimates of additive genetic $\left(\mathbf{V}_{\mathbf{A}}\right)$, permanent environmental $\left(\mathbf{V}_{\mathbf{P e}}\right)$, phenotypic $\left(\mathbf{V}_{\mathbf{P}}\right)$ and résiduel $\left(\mathbf{V}_{\mathbf{E}}\right)$ variances are presented in Figures (1), (2), (3) and (4) for test-day milk, fat, protein yields and age at first calving(AFC). The additive genetic variance $\left(\mathrm{V}_{\mathrm{A}}\right)$ estimates at first test day were $4.7 \mathrm{~kg}, 13.3 \mathrm{~g}$, $5.3 \mathrm{~g}$ and 2.8 month then they increased at the fourth test day to be $7.6 \mathrm{~kg}, 38.7 \mathrm{~g}, 14.3 \mathrm{~g}$ and 3.5 month and decreased thereafter, reaching the lowest value at the tenth test day for milk yield $(3.4 \mathrm{~kg})$ and at the tenth test day for fat, protein yield and age at first calving $13 \mathrm{~g}, 7.7 \mathrm{~g}$ and 5.7 month. Similar results have been reported by (Biassus et al. 2011) and (El Faro 2012)reported that the genetic variance values 
ranged from 2.3 to $5 \mathrm{~kg}$, from 1 to $7.5 \mathrm{~g}$ and from 1 to $5 \mathrm{~g}$ for TDMY, TDFY and TDPY, respectively.

Permanent variance estimates(Vpe) rangedfrom4.6 to $12.7 \mathrm{~kg}, 30.9$ to $69 \mathrm{~g}, 10.6$ to $23.9 \mathrm{~g}$ and 2.6 mo to $8.6 \mathrm{mo}$, for TDMY, TDFY, TDPY and AFC respectiviley. Simler trends werealsoreported by (Jamrozik and Schaeffer 1997) and (Jensen et al. 2001) in cattle.The residual variance estimâtes(Ve) for all traits rangedfrom $8 \mathrm{~kg}$ to $11 \mathrm{~kg}, 0$ to $8 \mathrm{~g}, 1 \mathrm{~g}$ to $4 \mathrm{~g}$ and from 16 to $23 \mathrm{mo}$ for milk, fat, protien and AFC traits,res pectively.

The phenotypic variance $\left(V_{P}\right)$ estimates for milk, fat, protein and age at first calving traits rangedfrom19.2 to $26.3 \mathrm{~kg}, 45.6$ to $113 \mathrm{~g}, 17.9 \mathrm{~g}$ to $41.5 \mathrm{~g}$ and $24.7 \mathrm{mo}$ to $34.8 \mathrm{mo}$, respictively. The phenotypic variance for the milk testdaydecreaseduntil TD6whichitwas 19.6 $\mathrm{kg}$ thenincreaseduntil the TD10 whichitwas $23.9 \mathrm{~kg}$. The

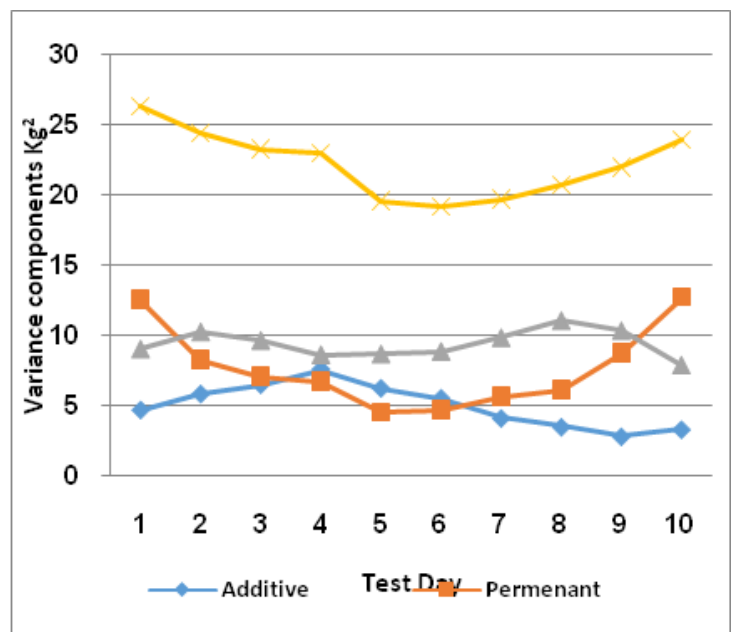

Fig. 1.Estimates of additive genetic $\left(\mathrm{v}_{\mathrm{A}}\right)$, permanent environmental $\left(\mathrm{V}_{\mathrm{Pe}}\right)$, residual variances $\left(\mathrm{V}_{\mathrm{E}}\right)$ and phenotypic variances $\left(\mathrm{V}_{\mathrm{P}}\right)$ for test day milk yield $(k g)$.

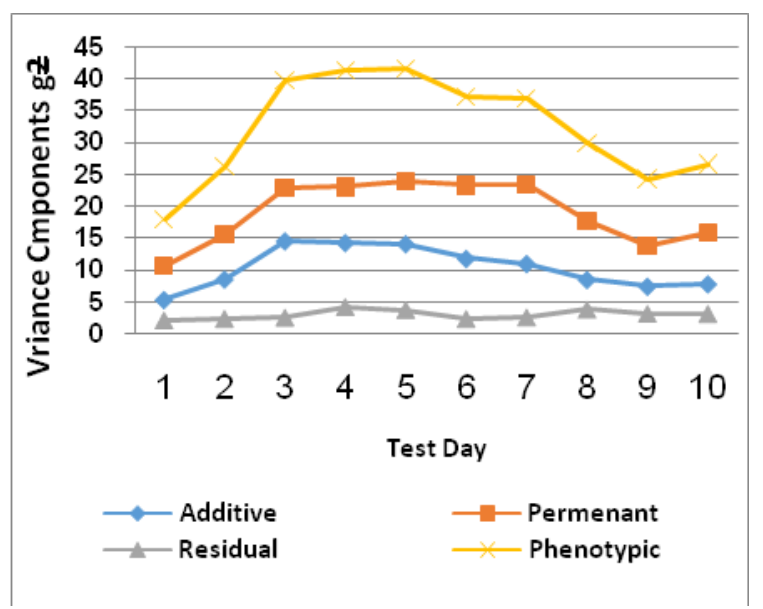

Fig. 3. Estimates of additive genetic $\left(\mathbf{V}_{\mathrm{A}}\right)$, permanent environmental $\left(\mathrm{V}_{\mathrm{Pe}}\right)$, residual variances $\left(V_{E}\right)$ and phenotypic variances $\left(V_{P}\right)$ for test day protein yield $(g)$.

\section{Heritability values:}

Heritability estimates for TDMY at selected TD are shown graphically in (Figure 5). Estimates were fat test-dayincreaseduntil TD4, itwas $113.1 \mathrm{~g}$ thenitdecreaseduntil TD7, itwas 99,9gthendecreaseduntil TD10, itwas $55.2 \mathrm{~g}$. Thesame trend wasobtained for protien trait. For AFC trait $\mathrm{V}_{\mathrm{A}}$ decreaseduntil TD6, 21.27 mo thenitincreaseduntil TD7 to be 24.12 mo, thenincreaseduntil TD10 whichreached 24.7 mo. Theseresultswere agreementwiththose of(Biassus et al. 2011)whoshowedthat the values of phenotypic variances rangedfrom 20 to $27 \mathrm{~kg}, 25$ to $35 \mathrm{~g}$ and 20 to $35 \mathrm{~g}$ for TDMY,TDFY and TDPY respictively. (El Faro et al 2012)revealedthat the phenotypic, permanent and genetic variances rangedfrom 2 to 7 $\mathrm{kg}, \quad 1.8$ to 5 and 0.2 to $1.2 \mathrm{~kg}$ for TDMY.Thes eresults werenearlys imilar thosereportedby(Cobuci et al 2005) permanent and geneticvariaces values rangedfrom 19 to $29 \mathrm{~kg}$ and 8 to $20 \mathrm{~kg}$ for TDMY respectiviley.

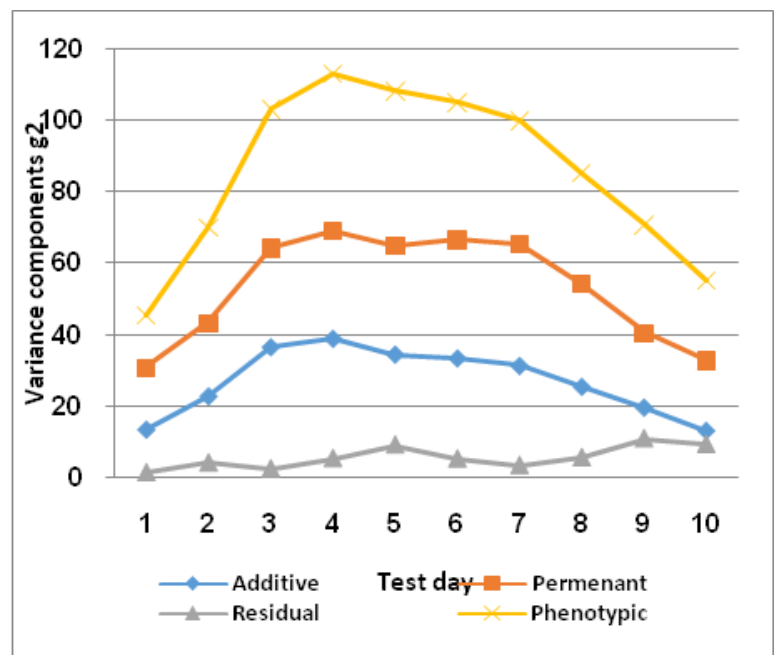

Fig. 2. Estimates of additive genetic $\left(\mathrm{v}_{\mathrm{A}}\right)$, permanent environmental $\left(\mathrm{V}_{\mathrm{Pe}}\right)$, residual variances $\left(\mathrm{V}_{\mathrm{E}}\right)$ and phenotypic variances $\left(\mathrm{V}_{\mathrm{P}}\right)$ for test day fat yield $(g)$.

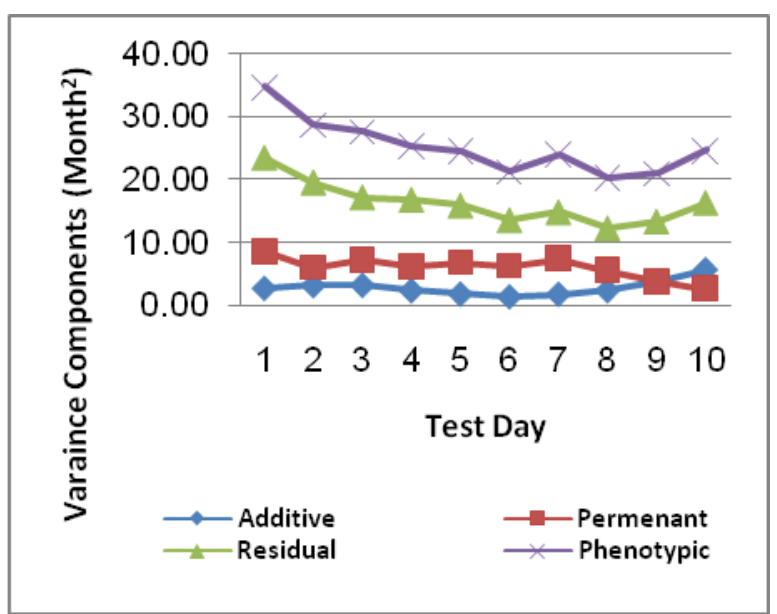

Fig. 4. Estimates of additive genetic $\left(V_{A}\right)$, permanent environmental $\left(\mathrm{V}_{\mathrm{Pe}}\right)$, residual variances $\left(V_{E}\right)$ and phenotypic variances $\left(V_{P}\right)$ for age at first calving (AFC).

low at the beginning of the test day (0.17), and gradually increased reaching the highest value at the fourth test day (0.33) and decreased gradually until 
they reached the lowest value at the tenth test day of lactation (0.14). The heritability estimates for fat and protein yields showed the same trend where the estimates were 0.29 and 0.3 on the first test day and reached 0.35 and 0.36 at the fourth test day, and finally decreased at the ninth test day in fat $(0.24)$ and at the tenth test day in protein yield (0.29). Similar trends were reported by Rosati and (Van Vleck,2002)for milking cows. Heritability estimates for AFC were low at the beginning of the test day (0.07), and gradually increased, reaching the highest value at the third test day (0.12) and decreased in the sixth test day (0.07), and then it increased until the tenth test day whenit was 0.24 .
In general, heritability estimates for traits had wide ranges and tended to increase toward the edges of the defined lactation trajectory. Most heritability estimates obtained by RRM were high at the edges as stated by(Jamrozik and Schaeffer, 1997)in dairy cows. Difficulties in the model in getting acceptable variances at the extremes of the lactation can be explained, in part, by the biological processes that occur at the beginning of lactation and the smaller number of records at the end. Jamrozik and Schaeffer (1997) and El- Saied (2004) pointed out that these parametric functions tend to overestimate the genetic variances and underestimate the genetic correlations among milk yield at the beginning and the end of lactations.

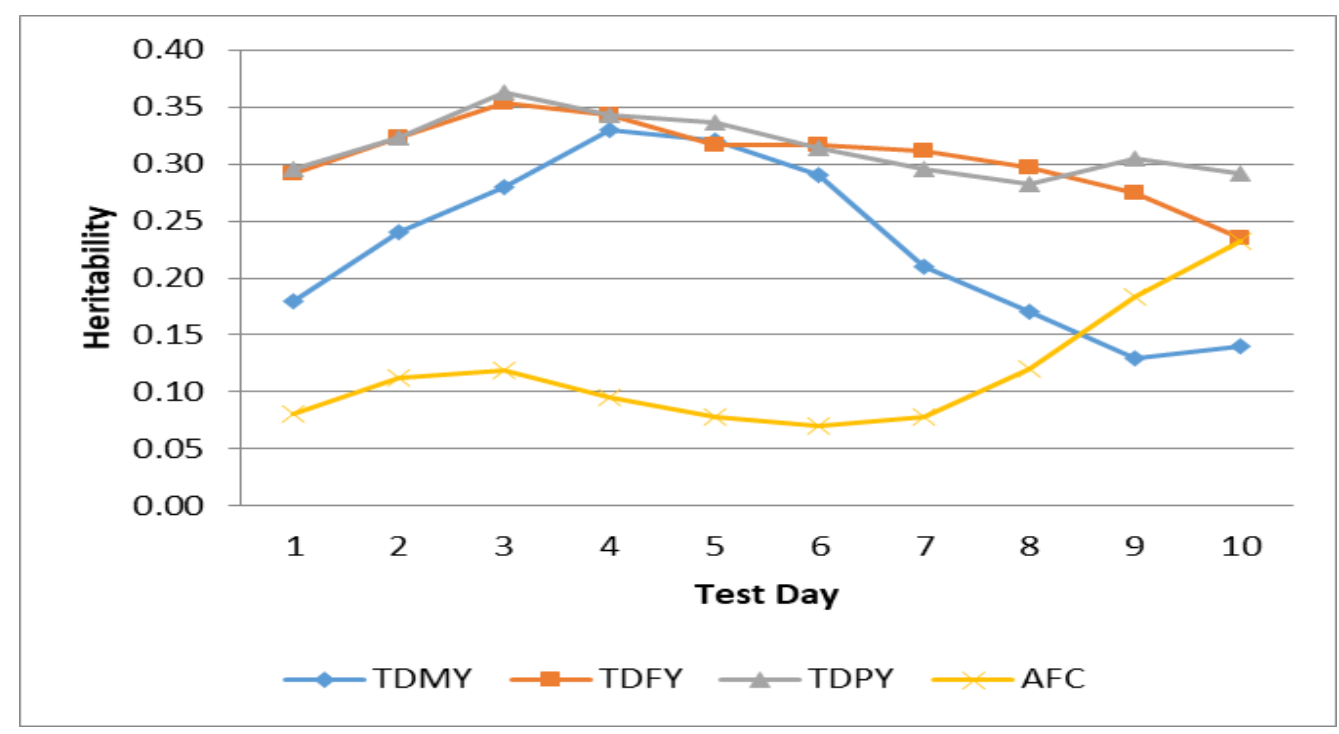

Fig. 5.Estimates of heritability of test-day milk (TDMY), fat (TDFY) and protein (TDPY) yields and age at first calving (AFC).

\section{Predicted breeding value $(P B V)$ :}

The minimum and maximum predicted breeding values (PBV) and their accuracies for milk, fat and protein yields and age at first calving are given in Table 4. The PBV for milk, fat and protein yields and age at first calving ranged from -1297 to $1896 \mathrm{~kg},-5.9$ to $6.2 \mathrm{~kg}$ and -7.1 to $7.5 \mathrm{~kg}$ and -2.6 to $2.4 \mathrm{month}$, respectively. Using TD animal model methodology in cattle, (Zutere, 2008) found that the estimated breeding values for milk, fat and protein ranged from -1014 to $1966 \mathrm{~kg}$, from -40.75 to $93.59 \mathrm{~kg}$ and from 37.33 to $59.86 \mathrm{~kg}$, respectively. The accuracies $\left({ }^{\mathbf{r A}}{ }^{\wedge}\right)$ of minimum and maximum estimates of PBV were high in all traits (Table 4). This may be due to that estimate of heritability were highly associated with more available pedigree information for all individuals (Korhonen, 1996; Korsgaard et al., 2002).

Table 4.Minimum, maximum and ranges of predicted breeding values (PBV), predicted error variance $(\mathrm{PEV})$ and accuracy of prediction $\left({ }^{\mathrm{r}{ }^{\wedge}}\right)$ for test day milk yield (TDMY), fat and protein yieldsin Friesian cattle raise in Egypt

\begin{tabular}{llllllll}
\hline Trait & \multicolumn{3}{c}{ Minimum } & & Maximum & & $\begin{array}{c}\text { Range } \\
\text { PBV }\end{array}$ \\
& PBV & PEV & $\mathbf{A}^{\wedge}$ & PBV & PEV & rA^$^{\wedge}$ & \\
\hline TDMY, kg & -1296.5 & 324.9 & 0.99 & 1895.6 & 634.0 & 1.00 & 3192.1 \\
Fat yield, kg & -5.9 & 4.1 & 0.89 & 6.2 & 5.2 & 0.92 & 12.1 \\
Protein yield, kg & -7.1 & 4.6 & 0.91 & 7.5 & 5.8 & 0.93 & 14.6 \\
Age at first calving, mo. & -2.6 & 1.2 & 0.65 & 2.4 & 1.7 & 0.78 & 5.0 \\
\hline
\end{tabular}

\section{Phenotypic trend:}

Phenotypic trend for TDMY, TDFY and TDPY and age at first calving are shown in Figure 6 . Phenotypic trends for TDMY, TDFY, TDPY and AFC were decreased from TD1 to TD10. The decrease in phenotypic trend in all traits may be attributed to low nutritional level applied and management practices in different herds. 

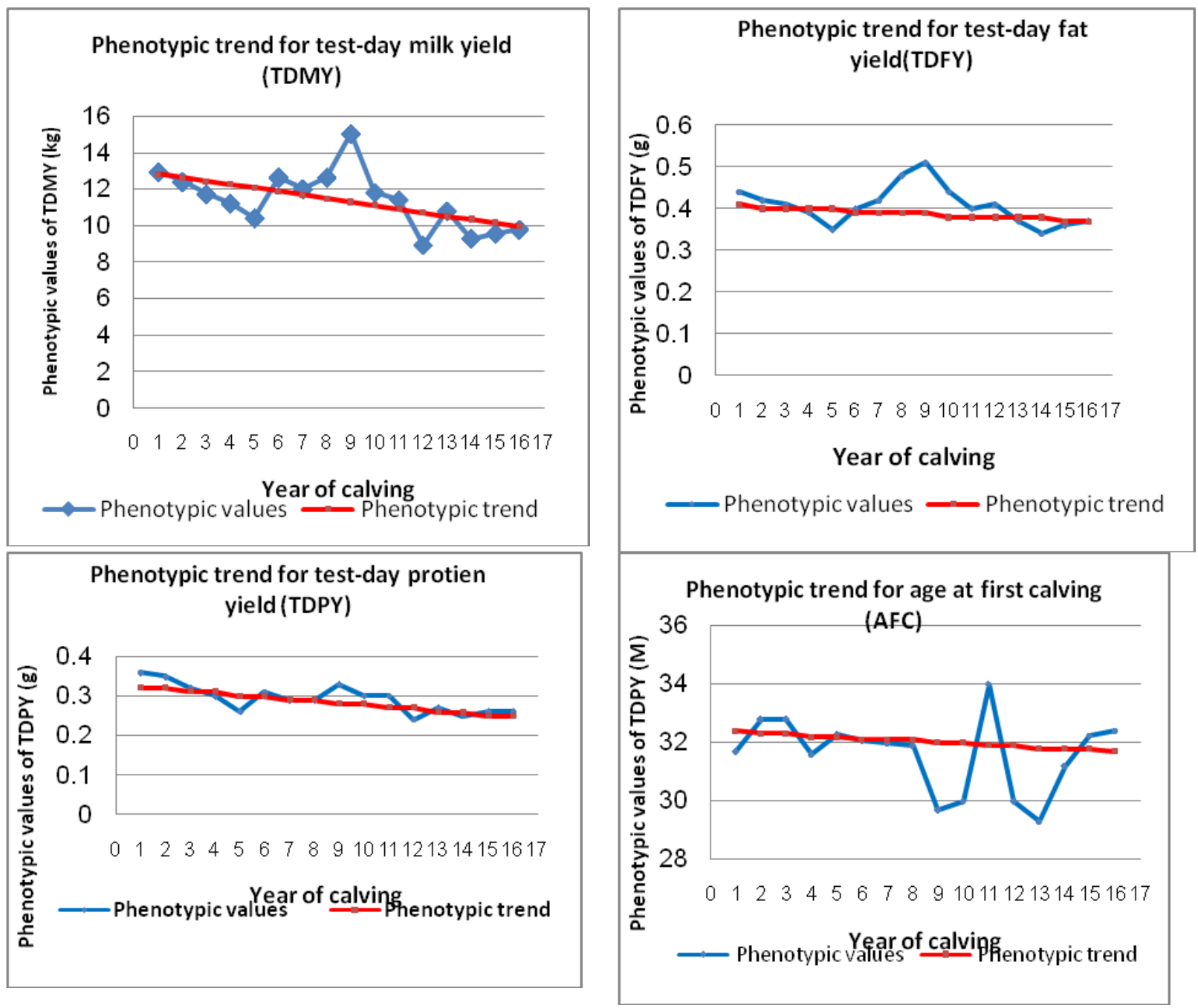

Fig. 6.Phenotypic trend for test-day milk, fat, protein yields and age at first calving in Friesian cattle raised in Egypt.

\section{Genetic trend:}

Genetic trend for TDMY, TDFY, TDPY and age at first calving are shown in Figure7, the values of genetic trend for TDMY, TDY, TDPY, and AFC traits increased from TD1 to TD10. These results indicated that improvement program of selection was

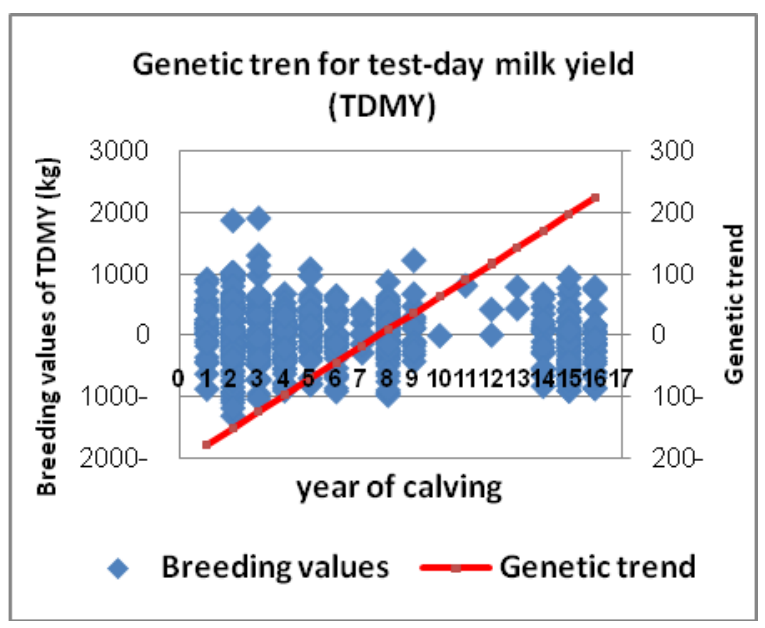

practiced in the farms. Similar trends were also reported by some investigators e.g.(Yaeghoobi et al2011) and (Katok and Yanar 2012),(Muller and Botha, 2003) for TDMY, (Jamrozik and Schaeffer, 1997).

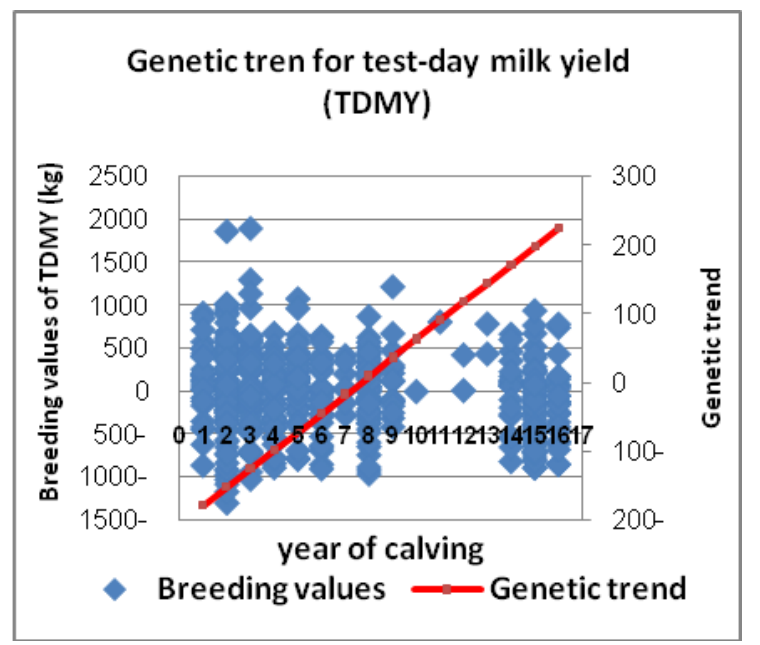



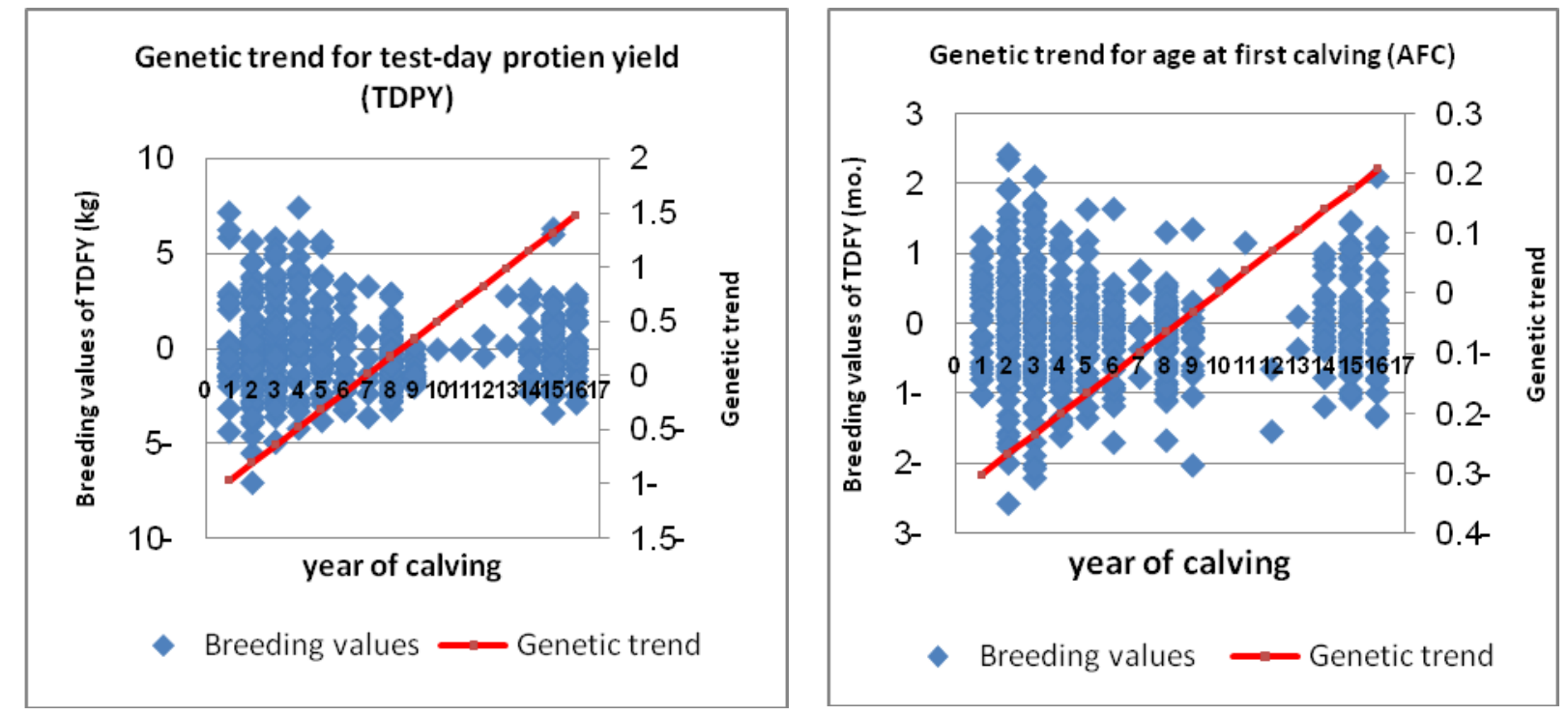

Fig. 7. Genetic trend for test-day milk, fat, protein yields and age at first calving in Friesian cattle raise in Egypt

\section{CONCLUSIONS}

1) The test-day milk yield during the first three to five months of lactation could be adopted as an early selection criterion to increase milk yield.

2) Random regression model (RRM) was considered to be efficient model in detecting the fluctuations in genetic variance during the lactation period. It would permit better modeling for repeated records throughout the lactation period and could be chosen as an accurate method for predicting breeding values.

3) Genetic trend showing the improvement of testday milk, fat, protein yields and age at first calving.So selection program was practiced correctly in this herd.

4)For all traits, the phenotypic trends showing deteriorating trends indicating the presence of some environmental inadequacies especially for nutritional level.

\section{REFERENCES}

Biassus I.O, JA. Cobuci, C.N. Costa, P.R.N. Rorato, J.B. Neto, and L.L. Cardoso, 2011.Genetic parameters for production traits in primiparous Holstein cows estimated by random regression models. R. Bras. Zootec., v.40, n.1, p.85-94.

Danell, B. 1982. Studies on lactation yield and individual test-day yield of Swedish dairy cows: III Persistency of milk yield and its correlation with lactation yield. Acta. Agriculture Scandinavica, 32:93-101.

El Faro L, Cardoso V. L and de Albuquerque L. G 2012.Variance component estimates applying random regression modelsfor test-day milk yield in Caracu heifers. Genetics and Molecular Biology, 31, 3, 665-673

El-Saied, U. M., 2004. Random regression estimation of genetic parameters for milk yield and protein test day model for percentage of
primiparousFrisian cows in Egypt. Egyptian $\mathrm{J}$. Anim. Prod., 41 (1): 1-10.

Groeneveld, E., KovačM, and MielenzN, 2010.VCE 6 , Users guide and reference manual, Version 6.0.2.

Groeneveld, E., Kovac M., andWang T, 2001. PEST, Users guide and reference manual, Version 4.2.3.

Henderson, C.R. 1975.Best linear unbiased estimation and prediction under a selection model. Biometrics 31(2): 423-447.

Jamrozik, J., Schaeffer, L.R., 1997.Estimates of genetic parameters for a test day model with random regressions for yield traits of first lactation Holsteins. J. Dairy Sci. 80:762-770.

Jensen, J., Jamrozik J. and Schaeffer L. R, 2001.Modelling production in all lactations in dairy cattle using random regression test day models. Book of Abstract proc. 52nd Annu. Mtg.of the EAAP. August, 26-29,2001,Budapest.

Katok, N. and Yanar M 2012. Milk traits and estimation of genetic, phenotypic and environmental trends for milk and milk fat yields in Holstein Friesian cows. Int. J. Agric. Biol., 14: 311-314.

Kennedy, B. W. 1989.ANIMAL MODEL BLUP Crasmus intensive graduate course.University of Guelph, Dublin.

Keown, J. F. and VanVleck, L. D. 1971.Selection on test-day fat percentage and milk production. J. Dairy Sci., 54:199-203.

Kirkpatrick, Lofs vold M., D., and Bulmer M., 1990.Analysis of the inheritance, selection and evolution of growth trajectories.Genetics., 124: 979-993.

Korhonen, T. (1996)."The dairy cattle evaluation of 1996.http://www.mloy.fi/faba/blup/blup1.html,23 .01.1977(h:14:13)(Article).

Korsgaard, I.R.; Andersen, A.H. and Jensen, J. 2002. Prediction error variance and expected response to selection, when selection is based on the bes $t$ predictor for Gaussian and threshold characters, 
traits following a Posiion mixed model and survival traits. Genet. Sel. Evol., 34:307-333.

Meyer, K. 1998b. Modeling repeated record: Covariance function and random regression models to analyze animal breeding data. 6th WCGALP. 25:512-520. Armidale, Australia.

Muller, C.J.C., and Botha J.A, 2003.The response to selection during first lactation on the phenotypic and genetic trends in the Elsenburg HolsteinFriesian herd. South African Journal of Animal Science , 33 (2): 111-116.

Ptak, E., Schaeffer, L.R., (1993).Use of test day yields for genetic evaluations of dairy sires and cows.Livest. Prod. Sci. 34:23-34.

Rosati, A., and L. D. Van Vleck, 2002.Estimation of genetic parameters for milk, fat, protein and Mozzarella cheese production in Italian river buffalo population. Livest. Prod. Sci. 74:185-190.

Schaeffer, L.R., 2004.Applications of Random Regression models in animal breeding.Livest. Prod. Sci. 86:35-45.
Schaeffer, L.R., Dekkers, J.C.M., 1994. Random regressions in animal models for test day production in dairy cattle. Proc $5^{\text {th }}$ World Congr.Genet.Appl. Livest. Prod., Guelph, ON, Canada, 18:443-446.

Takma c. and Akbas y, 2007.Estimates of genetic parameters for test day milk yields of a Holstein Friesian herd in Turkey with random regression models. Arch. Tierz., Dummerstorf50 4, 327336.

Wilmink, J. B. M. 1987. Efficiency of selection for different cumulative milk, fat and protein yields in first lactation. J. Dairy Sci., 17:211-224.

Yaeghoobi, R., Doosti A, Noorian A.M and Bahrami A.M, 2011.Genetic parameters and trends of milk and fat yields in Holstein's dairy cattle of west provinces of Iran. Int. J. Dairy Sci., 6: 142-149.

Zutere, R. 2008.Estimates of breeding values for dairy cattle using test-day milk yields.Agronomijas Vestis (Latvian Journal of Agronomy), 10: 293-299.

\title{
الإتجاه الوراثى والمظهرى لصفات إنتاج اللبن والعمر عند أول ولادة بتطبيق نموذج الإتحدار العشوائى فى ماثية الفريزيان فى مصر الأجر
}

\author{
محمد حماده محمد'، مـاهر حسب التبي خليل'، محمود مغزبى عر اقى'، سميح محمد زاهد' \\ ـ ـ معه بحوث الإنتاج الحيوانح، مركز البحوث الزراعية، r ـ قسم الإنتاج الحيوانس، كلية الزراعة بمشتهر، جامعة بنها
}

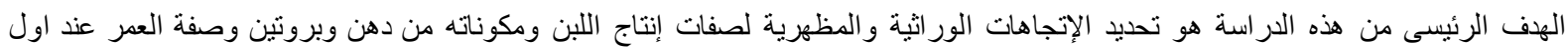

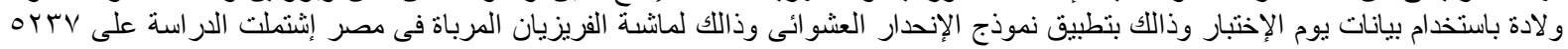

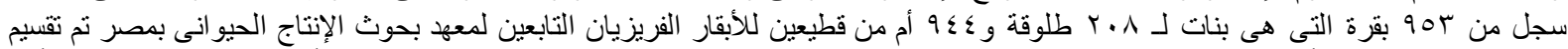

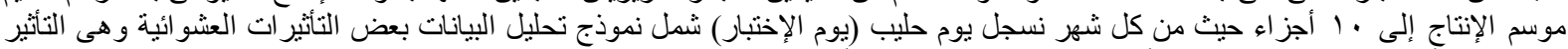

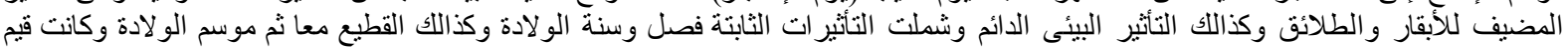

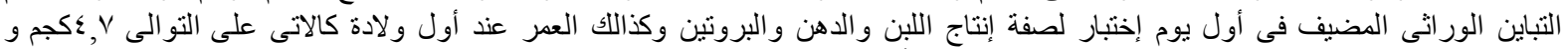

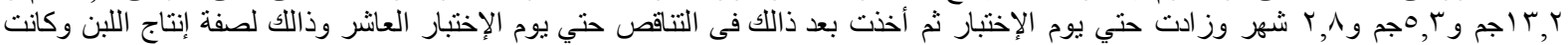

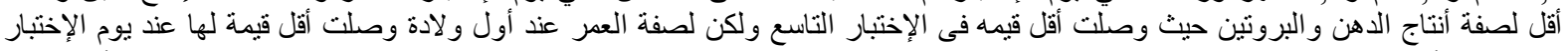

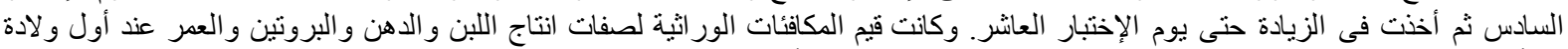

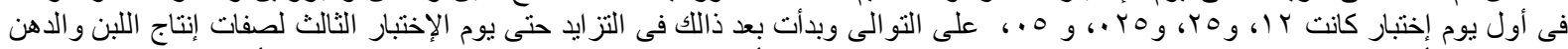

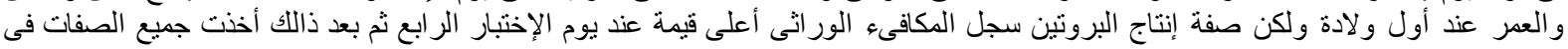

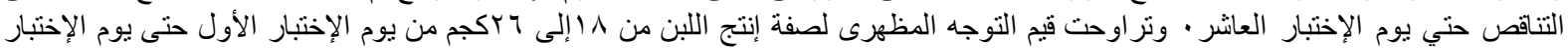

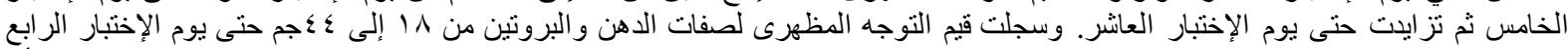

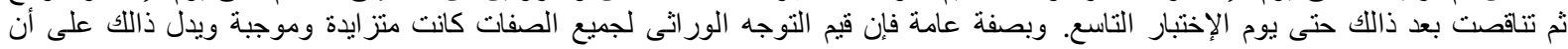
بر امج الإنتخاب تعمل بطريقة صحيحة. 